\title{
Modelling Owner Experience: Linking Theory and Practice
}

\author{
Barbara Orser, Deloitte Chair in the Management of Growth \\ Enterprises, School of Management, University of Ottawa
}

\author{
Marzena Cedzynski, Sprott School of Business, Carleton University, \\ Ottawa
}

\section{Roland Thomas, Sprott School of Business, Carleton University, Ottawa}

\begin{abstract}
This paper reports on the findings of research that seeks to construct and test an owner experience index. By doing so, the relationships among stage of firm, years of management experience (stock) and breadth (diversity) of experience are also examined. The latent structure of experience is best described by a six-factor solution, the dimensions of which include: small firm, operational, fiscal, marketing, technology, and innovation management. Contrary to previous research, this study suggests that, with the exception of technology-related experience, all dimensions of experience are stable across stage of firm. At the variable level, adopting new technology, new product development, on-line communications, promotions and advertising, and software skills have the highest discrimination power between business owners who intend to grow the firm and those who do not. The implications for future research are considered.
\end{abstract}

SOMMAIRE. Cet article présente les résultats d'une recherche visant à construire et tester un index d'expérience des propriétaires. Ce faisant, on examine également les relations entre le stade de l'entreprise, les années d'expérience en gestion (réserve) et l'étendue de l'expérience (diversité). La meilleure description de la structure latente de l'expérience appartient à une solution à six facteurs illustrant les dimensions suivantes : petite entreprise, et aussi gestion opérationnelle, fiscale, technologique, de commercialisation et d'innovation. Contrairement à la recherche antérieure, celle-ci suggère que, à l'exception de l'expérience liée à la technologie, toutes les autres dimensions sont stables pour le stade où se trouve l'entreprise. Au niveau de la variable, l'adoption d'une nouvelle technologie, le développement d'un nouveau produit, les communications en ligne, les promotions et la publicité, ainsi que les habiletés logicielles possèdent le plus fort pouvoir discriminatif entre les propriétaires d'entreprises qui veulent grandir et les autres. Pour finir, on passe en revue les implications pour la recherche à venir.

Owner experience is central to firm growth and performance (Boyatzis, 1982; Chandler and Jansen, 1992; Chandler and Hanks, 1994; Leitch, 1995; Freel, 1998, 1999; Aliouat et al., 1999; Baldwin, 1997; Lefebvre and Lefebvre, 2000; Julien and Ramangalahy, 2003; Van Gils and Zwart, 2004). However, researchers have noted that the literature is fragmented, reflecting little consensus about the definition, construction and appropriate methodologies to examine experience (Reuber and Fischer, 1995; Smith and Morse, 2005). Terms such as skills, abilities, expertise and competencies are used interchangeably, and "it is not clear, whether experience should be an element (indicator) of entrepreneurial competency, an antecedent of competency or an outcome (consequence) of competency" (Smith and Morse, 2005: 10). Researchers also note a wide variety of measures and little consistency in how studies operationalize experience constructs (Fischer and Reuber, 1999: 30). 
The objective of this study is to develop and test an instrument for measuring aspects of experience. The paper seeks to build on the conceptual framework advanced by Reuber and Fischer (1999), who describe experience as reflective of stocks and streams of experience. Briefly, stocks of experience are "antecedents of present and future states" and are associated linearly with expertise and dominant logic (1999: 31). Streams of experience reflect the learning process and are continuous. This research focuses on the definition and measurement of experiential stock. Reuber and Fischers' conceptual model also suggests that experience is linked to cognitive decision-making. The paper therefore explores the association between stocks of experience, the conscious decision to pursue (or not) a growth strategy, and stage of firm development.

\section{Study Rationale}

Examining stocks of owner experience and their associations with growth intention are important for several reasons. First, researchers and practitioners seek clarification about the nature of entrepreneurial experience and competencies. For example, Lievens, Sanchez and Corte (2004: 882) note that a recent examination of the ABI/INFORM database on competency modeling found over 500 articles published between 1995 and 2003 . This compares to 87 articles between 1985 and 1995. Many training programs also seek to qualify owner experience during client intake and prior to venture start-up. Currently, training organizations, bankers, venture capitalists, government agencies and individuals employ a variety of diagnostics to assess, assist, and make decisions about SME owners. ${ }^{1}$ However, few diagnostics report scale construction, validity and reliability (Smith and Morse, 2005). This is a concern as trainers and educators may assume otherwise. ${ }^{2}$ Hence, development of reliable diagnostics may assist training agencies and business owners in better understanding clients' development needs and risks.

Second, the development of robust psychometrics and diagnostics employed in other professional domains (e.g., IQ, SAT, GMAT measures) encourages this sphere of study (Jaskolka, Beyer and Trice, 1985; Judge, Cable, Boudreau and Bretz, 1995). The widespread use of these metrics shows that it is feasible to develop measures of knowledge and ability. An important step in the development of entrepreneurial diagnostics is to build a cadre of indices. Such diagnostics can be employed in subsequent research to compare and contrast relevance and reliability and in theoretical paradigms to explain the links among experience, expertise, competence and performance (e.g., stocks versus streams of experience; managerial versus industrial versus entrepreneurial experience, etc.).

Third, researchers report a lack of conceptual development, data accessibility and

\footnotetext{
1. See sample "entrepreneurial" diagnostics at: The Entrepreneurialist Culture Quotient (http://www.dramatispersonae.org/ECQTest/ECQ(ns)TestAuto.htm); Business Development Bank of Canada, BDC (http://www.bdc.ca/en/business_tools/entrepreneurial_self-Assessment/Entrepreneurial_self_ assessment.htm); Department of Foreign Affairs and International Trade (http://www.exportdiagnostic.ca/); and The Leadership and Management Development Council of British Columbia (http://www.leadershipmanagement.bc.ca/). With the exception of the BDC (Gasse and Tremblay, 2006) none of the above diagnostics provide information about their history, construction or reliability. See also US-based consortiums such as Competency-based Economies through Formation of Enterprise (http://www.cefe.net/forum/cefe-en.pdf) and The Consortium for Entrepreneurship Education (http://www.entre-ed.org/Standards_Toolkit/), and UK partnerships such as the INOVATE project (http://www.agentfactory.com/Inovate/Home.htm), as cited by Smith and Morse (2005).

2. For example, a recent Canadian study of small business advisors about management skill diagnostics suggests respondents' primary concern was increased awareness of and access to existing tools (Industry Canada, 2006: ii). Respondents also indicated that tool validation would help advisors select effective ones and increase the buy-in of entrepreneurs.
} 
methodological issues (Smith and Morse, 2005) and note the need to identify or specify types of experience that are consequential to venture performance (Fischer and Reuber, 1999). Moreover, much of the empirical research has focused on large industrial firms or other large non-manufacturing businesses (McGee and Peterson, 2000: 22). As such, this paper builds upon Fischer and Reuber's $(1995,1999)$ well-received theoretical model of small firm founder experience, which is also suited to the longer-term objectives of this research program: to create a practical index of experience that can be employed by training agencies for client self-evaluation prior to program and/or venture start-up. Finally, examination of experience and owner intention is a suitable cognitive domain of study given research that reports intention is found to be a reliable predictor of behaviour (Cliff, 1998; Kruger and Carsrud, 1993; Kruger et al., 2000). Intention is also seen to moderate the influence of experience on competencies and venture performance. Finally, previous studies have relied heavily upon exploratory factor analysis to determine the underlying constructs of experience or competence. This paper seeks to build on this literature by employing confirmatory factor analysis and by examining the stability of experience over the stage of firm and owner intentions.

To do so, the next section presents a summary of the literature, including definitions of experience and findings about potential associations among experience, competence, intention and performance in the small-firm context. Study propositions are then advanced, and the research methodology and empirical findings are presented. The paper closes with a discussion of findings, study limitations and recommendations for future research.

\section{Review of Literature}

For the purpose of this research, experience is defined as exposure to or familiarity with a knowledge domain. Experience reflects involvement in an activity leading to an increase in expertise, knowledge, skill and competence (adapted from Encarta Dictionary, 2006). The majority of entrepreneurship studies that have examined owner experience have employed a definition that equates experience and expertise to duration of experience in business ownership or industry engagement (Smith and Morse, 2005: 11).

Employing financial metaphors to construct a conceptual paradigm of experience, Fischer and Reuber $(1995,1999)$ postulate that experience is comprised of stocks and streams of knowledge. Stock of experience is akin to a balance sheet, where an individual or a team possesses an inventory of accrued experiential assets at a given period of time. In the same way that there are different elements on a balance sheet, an individual or team will possess different types or stocks of experiences." Reuber and Fischer present two key properties of stock experience: depth and breadth or diversity of experience. Diversity is conceptualized as a number of functional areas, industries or organizations in which the owner has worked or managed. Depth reflects the tenure, duration or years of the experience. The model also posits that expertise is acquired through time and extensive repetition of experience and tasks. Reuber and Fischer $(1995,1999)$ surmise that depending on the environmental context, duration, tenure, or depth of experience can be viewed as an asset or liability. For example, experience may provide exposure to different environments, allowing individuals to discern different environmental threats.

Drawing on corporate workplace learning, performance can also be enhanced through input from diverse groups of individuals, high-stress situations, knowledge acquired through business conditions and setbacks (McCall, Lombardo and Morrison, 1988 as cited by Rueber and Fischer, 1999: 35). Familiarity may create loss of flexibility (or ability to 
swing with the punches), and/or slow down learning. Finally, stocks of experience have been characterized as assets with diminishing return and/or limited shelf life. Reuber and Fischer describe a second perspective of experience, coined "streaming." This perspective suggests that the learning process is continuous, although one would expect a very intense learning period when a venture is new. The primary focus on inquiry for examining streaming experiences is the firm. Conversely, the appropriate unit of analysis for examining stocks of experience is the owner or founder.

Orser (1997) defines experience as "managerial capacity" or the accumulation of knowledge of the owner and management team. She argues that managerial capacity reflects elements of commercial, human resource, financial, technological, networking, marketing and domestic experience. ${ }^{3}$ Gasse and Tremblay (2006), in the development of their "entrepreneurial awareness" instrument, postulate that experience is reflected within the profile or background attributes (e.g., age, gender, education, and parents). Their on-line instrument asks respondents two questions pertaining to business experience: "Have you ever worked for yourself" and "What is your occupational [level] and/or profession?" More recently, Lee and Tsang (2001: 590) suggest that entrepreneurs' experience consists of three components: entrepreneurial, industrial and managerial. Industrial experience refers to experience in the industry that the venture is in. Managerial experience is the total experience in management regardless of the industry. Entrepreneurial experience is defined as the number of previous new venture involvements and the level of the management role played in such a venture (as defined by Stuart and Abetti, 1990: 151).

Overall, researchers tend to use the terms experience and competence interchangeably (Smith and Morse, 2005). Hence, further examination of competence research is warranted. Competence differs (implicitly or explicitly) from stocks of experience in that experience is a precursor to competence. Jacobs and Pons (1994) define "competence" in terms of results, such as the ability to perform management functions effectively in a work-related situation. Hines (1995) views competencies as "outcomes rather than subject area." McCurry (1994) emphasizes interactions that lead to "solv[ing] real workplace problems," while McGowan et al. (2001:127) surmise that "[c]ompetencies are variously defined as the ability to use knowledge and skills effectively in the performance of a managerial role (Klemp, 1980; Boyatzzis, 1982; Middleton and Long, 1990).”

In a review of measures to estimate distinctive competencies, McGee and Peterson (2000) report that early research (primarily in the 1980s) employed nominal and singleitem scales to measure the relative strength of functional activities. For example, Snow and Hrebiniak (1983) asked executives to rate the firm's functional activities as strong, weak, or average. Functional activities included general management, financial, marketing/selling, market research, product and development, engineering, production, distribution, legal affairs and personnel. Subsequent small business research has witnessed an expansion in both the attributes of competence and in terms of assessment criteria that anchor competence (e.g., self-perceptions about ability, strategic significance, importance,

3. Orser (1997) asserts that traditionally, management studies have negated marketable experience derived through unpaid, volunteer, domestic or household economies, experience that is particularly relevant to the life experiences of women. This includes experiences acquired through household productivity (e.g., time management, balancing budgets, social skills, etc.).

4. See http://www.bdc.ca/en/business_tools/entrepreneurial_self-Assessment/Entrepreneurial_self_ assessment.htm. 
activities, awareness and adoption). Hitt and Ireland (1985) measured 55 distinctive competencies on a seven-point scale ranging from "greatest strategic significance" to "strategically insignificant." Acar (1993) employed a 14-item scale, Drodge, Vickery and Markland (1994) a 31-item scale, and Chandler and Hanks (1994) a 19-item scale. The number of underlying competency constructs continues to grow (e.g., Abraham, Karns, Shaw and Mena, 2001, 23 competencies; Van Der Heijden, 2000 as cited by Smith and Morse, 2005, 78 competencies; Entrepreneurial Competency Standards, 2005, 403 competencies). It is therefore not surprising that this area of inquiry reflects a broadening of what now constitutes competency. Examples include political competencies (Chandler and Jansen, 1992; Edelman, Brush and Manolova, 2001); market decision-making competencies (Cummins, Gilmore and Carson, Undated); export competencies (Julien and Ramangalahy, 2003); technical capability/computer technology competencies (Zinger, LeBrasseur and Zanibbi, 2001); innovative competencies (Lefebvre and Lefebvre, 2000); Euro/SME management competencies (Eyre and Smallman, 1998); and process competencies (Chandler and Jansen; 1992; Woolgar et al., 1998; Iles and Yolles, 2002; Hansen, Sondergard and Meredith, 2002; Van Gils and Zwart, 2004).

Competencies have also been constituted as behaviours. Man and Lau (2001) report competence in terms of entrepreneurial behaviours including: opportunity competencies (e.g., recognizing market opportunities); relationship competencies (e.g., person-to-person or individual-to-group interactions); conceptual competencies (e.g., different conceptual abilities); organizational competencies (e.g., organization of internal/external human, physical, financial and technological resources); strategic competencies (e.g., seeing, evaluating and implementing the strategies of the firm) and commitment competencies (drive).

In summary, experience and competence are interrelated and multi-dimensional. Experience is a precursor of competence and is seen to reflect stocks and streams of primarily entrepreneurial, managerial, and functional knowledge encounters (Chandler and Jansen, 1992; Smith and Morse, 2005). Stocks of experience also reflect depth and diversity of knowledge and encounters that may lead to enhanced expertise. It is not clear how depth and diversity of experience are associated. The literature also reports that there are no well-received indices to capture the diverse composition of experience.

\section{Associations Between Experience and Venture Performance}

Research consistently reports links between management experience and venture performance (Cooper, Woo and Dunkleberg, 1989; Bates, 1990; Keeley and Rourse, 1990; Van de Ven, Hudson and Schroeder, 1984). As Smith and Morse (2005: 11) report:

... Shane and colleagues (Shane \& Khurana, 2003; Shane \& Stuart, 2002) conceptualized human capital as an initial resource endowment using founders' previous experience (e.g., industry experience, start-up experience, firm financing experience). Using US patent data at MIT from 1980 and 1996, they found that only the industry experience variable was significantly related to time-to-IPO in the regression analyses. Similarly, Sapienza and Grimm (1997) posed that founder characteristics (general education level, number of business courses, and previous experience, among others) have direct impact on firm performance. Through a series of OLS regressions on a longitudinal survey data of 70 short-line railroads, they found significant relationships. Although they 
also included strategy and structure variables in the model, they only tested these models separately. More recently, Wang \& Ang (2004) included management's experience in the model as a part of resource capabilities. Through multiple regression analysis on 40 venture-capital backed firms in Singapore, they also found a significant relationship between experience and subjectively measured firm performance. Other examples can be found in Honig (1998), van Praag and de Wit (2001), and de Clercq and Arenius (2003).

However, the relationship between experience and venture performance is neither straightforward nor linear. Lee and Tsang (2001) present a multivariate framework model (employing partial least squares method) to examine the influence of experience, education, personality (need for achievement, internal locus of control, self-reliance, and extroversion), size of partnership(s), networks and size and nature of communications on venture performance. Results indicated that experience, networking, number of partners, and personality (internal locus of control, need for achievement) had a positive impact on venture growth. Self-reliance and extroversion had a negative impact on number of partnerships and a positive impact on networking activities. "Our findings indicate that among all the factors that we have considered, entrepreneurs' industrial and management experience is the dominating factor affecting venture growth" (Lee and Tsang, 2001: 583).

Six Canadian studies further demonstrate the complex association between experience (expertise, competence) and venture performance. Dyke, Reuber and Fischer (1992) employ a composite estimate of experience (e.g., years of owner experience, years of experience with similar products and services, years in previous businesses which the owner helped to start, and business ownership previous to owning the current firm) to examine the association between experiences and venture performance. Not all stocks of experience were linked to performance. Previous experience in management, previous experience in the industry in which the current firm operates, and previous start-up experience were positively associated with performance. However, number of years of previous business ownership (experience running an entrepreneurial firm) was not related to performance. Orser (1997) employed logistic regression to examine the associations among a second composite of experience (management capacity), owner intention and (high/low) firm growth. Breadth or diversity of experience was based on total number of experiences the respondents had undertaken within 4 functional areas (general management, strategic management/planning, human resource management and marketing). Less diversity of management experience, the intention not to expand the firm, and being female were associated with low-growth ventures. Conversely, diversity of management experience, being male, and an intention to grow were associated with high growth. Similarly, Gasse (1997) and Newton (2001) report about the temporal nature of experience and competence. Both researchers suggest that competencies or expertise and experience change or evolve over the stage of the firm.

Mitchell, Mitchell and Smith (2004) examined the relationship among venture failure, experience, and perceived expertise in order to determine if less-experienced entrepreneurs were "untempered", "unskilled and unaware" (as argued by Kruger and Dunning, 1999). "In our focused interviews we sought to resolve the apparent paradox for lowexperience entrepreneurs: that if you haven't failed you are less likely to accurately assess

5. The study employed a self-report multi-item scale to estimate experience (e.g., I have started three or more businesses, at least one of which is a profitable, on-going entity; I have started at least one business that has 
your own expertise..." The team reported high confidence levels in the comments of lowexperience entrepreneurs who had not failed. Conversely, new venture failure experience appeared to have played a positive role in start-up expertise.

Finally, Zinger et al. (2001) report on a three-factor construct of experience (managerial, marketing and technical capabilities), drawn from 10 questions measuring management capability. Marketing ability was the most significant catalyst of micro-enterprise performance. The association between technology capability and performance was not significant.

Overall, it is observed that experience, competence, expertise, intention, and performance appear to be associated. While experience is one of many cognitive factors linked to performance, it seems also to be a dominant influence and experience tempers executive decision-making. It is not yet clear, however, what stocks or types of experience are more likely to be associated (if at all) with intention and stage of firm.

\section{Study Propositions}

The study first sought to examine the construct of "entrepreneurial" experience by posing the question: Is entrepreneurial experience a unique stock of experience or a subset of functional and industrial experience? In other words, can entrepreneurial experience be described adequately using traditional management categories such as general management, financial, marketing/selling, market research, and product and development (as described by Snow and Hrebiniak, 1983, among others)? Alternatively, is entrepreneurial experience significantly different from managerial and industrial experience? The study also sought to explore the relationship between diversity (breadth) and depth (years) of experience, the extent to which stocks of experience are acquired over time, and if specific type(s) of experience are associated with the intention of owners to grow the firm. To examine these questions, the following four sets of hypotheses are advanced:

Hla: Entrepreneurial experience is a subset of functional/managerial and industry experience.

$H 1 b$ : Entrepreneurial experience is a unique stock of experience that is significantly differentiated from functional/managerial and industry experience.

H2: Breadth (diversity) of owner experience is associated with depth (years) of owner experience.

H3a: Breadth (diversity) of owner experience is associated with stage of firm development.

H3b: Entrepreneurial experience is associated with stage of firm development.

H4a: Breadth (diversity) of experience is associated with owners' growth intentions.

H4b: Entrepreneurial experience is associated with owners' growth intentions.

been in existence for at least two years; I have significant career experience that makes me highly familiar with new venture formation). Expertise was measured through a single self-report item that asked respondents to rate level of expertise on a semantic differential scale with anchors of "Novice" and "Expert." In addition, measures of expertise were captured with respect to cognitive attributes such as perceived ability and willingness, cognitions reflecting ability, and cognitions associated with opportunity fit, venture diagnostic ability, opportunity recognition, commitment tolerance, seeking focus, and opportunity motivation (Mitchell et. al., 2000: 992). See quote at:

http://www.babson.edu/entrep/fer/FER_2004/web-content/Contents/Summary.html 


\section{Scale Construction}

\section{Research Methodology}

Experience was assessed using a 23-item scale. The list of experiences was generated from the literature pertaining to experience, previously tested questions (Reuber et al., 1994; Orser, 1997) and suggestions provided by two government agencies. All items were measured on a self-reported 5-point Likert scale, where $1=$ limited management experience, $3=$ some management experience and $5=$ extensive management experience with $6=$ "not applicable." Likert scales were employed for three reasons. First, in a review of self-evaluation experience / competency measurement scales, McGee and Peterson (2000: 24) report that Likert scales have been used consistently by researchers. Second, an earlier iteration of the instrument employed Likert scale measures that were piloted and field tested by a member of the research team and found to be satisfactory. Third, the Likert scale employed is applicable to the theoretical framework employed in this study. The scales employed are presented in Appendix A.

To estimate depth (years) of experience, respondents were asked to report on years of business management experience and years of business management experience in the present business. Drawing on Gasse (1977) and Newton (2001), stage of firm was described as start-up, initial growth, fast-growth, mature, turnaround, and winding down. To estimate business owners' growth intentions, respondents were asked to indicate yes or no to the following question: "During the next two years, is it your intention to expand the size or scope of your business?" This scale was also developed, piloted and field-tested in earlier work by a member of the research team. ${ }^{6}$

\section{Sampling}

The sampling frame consisted of SME owners drawn randomly from a commercial database. The sampling was undertaken in two phases. Phase one entailed a fax-back survey administered in Spring 2001. Phase 2 entailed a follow-up telephone survey two and a half years later, in Winter 2003. Of the 1,002 respondents in the 2001 WEI sampling frame, interviewers in 2003 were unable to contact 234 respondents, and 60 potential respondents were no longer in business. Of the remaining 707 eligible respondents, 223 refused to participate, 142 failed to return any of more than three calls, and another 16 were eliminated for miscellaneous reasons. There were 326 telephone surveys completed, a $46.2 \%$ response rate among eligible respondents.

A comparison between the sampling frame and the original sample was undertaken to investigate survivorship and non-response biases. Using standard chi-square tests to examine the distributions of salient attributes (sales, number of employees, sector), there were no statistically significant differences (p-value of less than 0.05 ) in owner or firm characteristics between the baseline data available in the sampling frame and the corresponding attributes of respondents.

\footnotetext{
6. Respondents were asked three questions pertaining to their perceptions of growth: Specifically, respondents were asked to indicate the likelihood of growth, i.e., how likely they thought it was that they would "expand the scope and size of the business in the next six months." A second question queried the extent to which owners thought growth was beneficial or determined based on value scores ranging from extremely good to extremely bad. A third question sough to rate the importance of growing their business. A Chronbach alpha test was undertaken to estimate scale reliability. The estimated Cronbach alpha was large (0.91). The growth likelihood question was deemed a reliable question for testing the concept of growth intention.
} 


\section{Empirical Findings}

Respondents' attributes are summarized in Tables 1 and 2. Male business owners accounted for two-thirds of the sample (67.3\%). Approximately half of the business owners surveyed were less than 50 years of age with the majority falling into the 30-49 year age group; approximately $50 \%$ of respondents sought growth. Three-quarters of those surveyed had created or participated in the creation of the business. Of the respondent

\begin{tabular}{|c|c|c|c|c|}
\hline \multicolumn{5}{|c|}{ Table 1. Descriptive Statistics } \\
\hline & & Male $(n=219)$ & Female $(\mathrm{n}=207)$ & Total $(n=326)$ \\
\hline \multicolumn{5}{|l|}{ Owner Attributes } \\
\hline \multicolumn{5}{|l|}{ Owner Age } \\
\hline & $30-39$ & 2.3 & 1.9 & 2.1 \\
\hline & $40-49$ & 11.4 & 13.1 & 12 \\
\hline & $50-59$ & 33.3 & 32.7 & 33.1 \\
\hline & More than 59 & 40.2 & 43.9 & 41.4 \\
\hline \multicolumn{5}{|l|}{ Education } \\
\hline & No Tertiary & 12.8 & 8.4 & 11.3 \\
\hline & College Graduate & 54.4 & 43.3 & 50.6 \\
\hline & $\begin{array}{l}\text { University or } \\
\text { University Grad }\end{array}$ & 17.2 & 17.3 & 17.2 \\
\hline & Other & 28.4 & 39.4 & 32.1 \\
\hline \multicolumn{5}{|c|}{ Total years of work experience } \\
\hline & $0-9.9$ & 2.7 & 10.3 & 5.2 \\
\hline & $10-14.5$ & 8.2 & 19.6 & 12 \\
\hline & $15-19.9$ & 15.1 & 21.5 & 17.2 \\
\hline & $20-24.9$ & 15.1 & 15 & 15 \\
\hline & $>25$ & 16.4 & 15.9 & 16.3 \\
\hline \multicolumn{5}{|l|}{ Firm Attributes } \\
\hline \multicolumn{5}{|c|}{ \# of Employees (FTE) 2002: } \\
\hline & None & 16.7 & 29.0 & 20.5 \\
\hline & $1-4.9$ & 44.1 & 45.0 & 44.4 \\
\hline & $5-19.9$ & 30.2 & 22.0 & 27.6 \\
\hline & More than 19.9 & 9.0 & 4.0 & 7.5 \\
\hline \multicolumn{5}{|c|}{ Annual Revenue-2002: } \\
\hline & Less than $\$ 100,000$ & 21.7 & 34.0 & 24.6 \\
\hline & $\$ 100,00-\$ 499,999$ & 31.4 & 41.5 & 33.8 \\
\hline & $\$ 500,000-\$ 1,000,000$ & 19.4 & 9.4 & 17.1 \\
\hline & $>\$ 1,000,000$ & 27.4 & 15.1 & 24.6 \\
\hline \multicolumn{5}{|l|}{ Stage of Business: } \\
\hline & Start-up & 1.2 & 0.0 & 0.8 \\
\hline & Growth & 31.1 & 39.0 & 33.6 \\
\hline & Maturity & 67.7 & 61.0 & 65.6 \\
\hline \multicolumn{5}{|l|}{ Sector: } \\
\hline & Service Industry & 33.8 & 38.8 & 35.5 \\
\hline & Retail Industry & 52.2 & 54.1 & 52.8 \\
\hline & Goods Industry & 13.9 & 7.1 & 11.7 \\
\hline & & $\mathrm{N}$ & Mean & Std. Dev. \\
\hline \multicolumn{2}{|c|}{ Total years of management experience } & 323 & 19.43 & 10.47 \\
\hline \multicolumn{2}{|c|}{ EMPS-Number of FTE Employees } & 326 & 5.22 & 9.90 \\
\hline \multicolumn{2}{|c|}{ REV-2002 Revenue } & 260 & $1,048,123$ & $2,253,302$ \\
\hline
\end{tabular}




\begin{tabular}{|l|c|c|c|}
\hline Table 2 Descriptive Statistics about Experience \\
\hline Stocks of experience & $\mathrm{N}(326)$ & \% Non-Applicable & Mean \\
\hline Electronic commerce & 184 & 43.6 & 1.77 \\
\hline Adopting new technology & 205 & 36.8 & 2.18 \\
\hline Accessing industry information & 257 & 20.9 & 2.30 \\
\hline Financial analysis & 264 & 19.0 & 2.57 \\
\hline Using market research & 264 & 19.0 & 2.59 \\
\hline Software skills & 268 & 17.8 & 2.84 \\
\hline On-line communications & 271 & 16.9 & 3.15 \\
\hline Accessing fields of knowledge & 270 & 16.9 & 2.46 \\
\hline Operations management & 278 & 14.7 & 4.14 \\
\hline New product development & 279 & 14.1 & 3.44 \\
\hline Delegating & 285 & 12.6 & 3.92 \\
\hline Industry standards & 273 & 12.0 & 2.67 \\
\hline Sources of capital & 289 & 11.0 & 2.61 \\
\hline People management & 292 & 10.4 & 3.80 \\
\hline Financial reporting & 295 & 9.5 & 3.34 \\
\hline Project management & 296 & 9.2 & 3.95 \\
\hline Promotion and advertising & 305 & 6.4 & 3.33 \\
\hline Professional networks & 311 & 4.6 & 3.63 \\
\hline Small business regulation & 318 & 2.5 & 3.98 \\
\hline Business plans & 320 & 1.8 & 3.53 \\
\hline Pricing & 320 & 1.8 & 4.24 \\
\hline Supplier/client relationships & 326 & 0.0 & 4.43 \\
\hline Small business management & 325 & 0.0 & 4.35 \\
\hline
\end{tabular}

firms, $65 \%$ employed five or fewer full-time equivalents (FTE); $28 \%$ of the firms employed 5-20 employees or FTEs; and 7\% employed more than 20 FTEs. The sector breakdown was not representative of the population of SMEs as a whole: respondent firms are relatively highly concentrated in the services and trade sectors, with few establishments in the goods-producing sector.

\section{Modeling Experience}

The purpose of this section of the paper is to arrive at a classification of experience and to uncover the latent underlying dimensions of experience. To do so, Mplus, a Structural Equation Modeling (SEM) software package, was employed to fit and test exploratory factor analysis models and structural equation models. The 23 experience items were assessed on the basis of the item-total statistics available in the reliability analysis. The item-total correlation for each variable exceeded 0.3. The high value of the Kaiser-MeyerOlkin (KMO) statistic $(0.820)$ also indicates that the data is adequate for factor analysis. Table 2 reports descriptive statistics for the responses to each of the 23 experience scales. A high number of "not applicable" responses to questions measuring "high-level" experiences (i.e., electronic commerce, adopting new technology, and assessing industry information) were observed. The incidence of "not applicable" responses was surprising given that the sample primarily comprised established firms. It is interesting that these experiences were generally associated with technology.

The number of non-applicable responses necessitated an assessment of the impact of the "not applicable" responses on the formation of latent factors. For example, almost half (43.6\%) of respondents indicated that electronic commerce, defined as "buying and selling commercial goods on the Internet," was "not applicable to you or your firm." 
Approximately $40 \%$ of business owners (26.8\%) responded that "adopting new technology," defined as "a leading-edge technology (e.g., business-to-business electronic marketing practices), was not applicable. Approximately two in ten respondents indicated "accessing industry information," "financial analysis," "using market research," and "software skills" were not applicable. Consequently, factor analysis was conducted under two scenarios. Under scenario 1, "not applicable" responses are treated as missing and the corresponding cases were removed from the analysis $(n=103)$. Under scenario II, "not applicable" responses (denoted value 6) are converted to a value of 1 , indicating "no experience" on the continuum defined by the 5 -point scale. The assumption that business owners who provided "not applicable" responses to questions measuring their experience in specific areas of business have no experience in that area seems justifiable, given that the average scores for questions with a high frequency of "not applicable" responses is low, where $n=309$. For example, questions assessing experience in electronic commerce, adopting new technology, and accessing industry information, respectively, were 1.77, 2.18, and 2.30 .

Thus, the analysis conducted under scenario 1 provides insight into the dimensionality of experience for business owners who find "higher level" knowledge applicable to their businesses. The analysis under scenario II covers a wider range of business owners including the less sophisticated firms. Moreover, because of the listwise exclusion of the missing cases, the sample under Scenario I constitutes one-third of the sample used in analysis under Scenario II (103 cases vs. 309 cases). The comparison of results for both scenarios sheds light on the question of experience stability across a range of companies (e.g., theory and practice). Statistics on the data fit of the tested models provide valuable information for determining whether or not further efforts to develop a better scale are warranted.

\section{Hypothesis Testing}

The first hypothesis tested (Hla: Entrepreneurial experience is a subset of functional/ managerial and industry experience) was based on the assumption that experience reflects traditional /functional areas of business (e.g., finance, marketing, technology management, human resources, general management, operations management) and entrepreneurial experiences. To test this hypothesis, the 23 experience items were grouped into one of these six functional categories, each of which defines a different traditional area of business experience (marketing, financial and capital management, human resources, operations and technology management). Discrete CFA (i.e., confirmatory factor analysis method that takes into account data discreteness) indicated that the data does not adequately fit the six-factor solution defined by the functional or traditional disciplinary definition of experience. The high value of the chi-square goodness-of-fit test ( $\rho$ value $<0.001$ ) indicated that the factors did not explain the inter-correlations among the variables in the model. The Root Mean Square Error of Approximation (RMSEA) statistic (0.111) and the Standardized Root Mean Square Residual (SRMR) statistic (0.091) suggested that the model may require modification (Hu and Bentler, 1999).

To examine the second hypotheses (H1b: Entrepreneurial experience is a unique stock of experience that is differentiated from functional/managerial and industry experience) the experience scales were grouped into three categories: managerial, functional and entrepreneurial. Again, the statistically significant chi-square test of absolute model fit ( $\rho$ value $<0.001)$ coupled with the high value of the SRMR statistic $(0.104)$ for the three-factor solution indicated inadequate data fit. 
Accordingly, neither Hypothesis 1a nor Hypothesis $1 \mathrm{~b}$ was supported by the data. Although the significance of the chi-square statistic (which is sensitive to sample size and non-normality in the input variables), may not be the most reliable test to determine if factors fit the data well - the value of the SRMR statistic above .08 points to problems with the tested scales (Hu and Bentler, 1999). Neither model accounts well for the correlations among variables. Lack of satisfactory fit of tested models continued to raise the question, what is the latent structure of business owner experience?

Scale reconstruction was then undertaken in two separate steps, first Scenario I $(\mathrm{n}=103)$ and then Scenario II $(\mathrm{n}=309))^{7}$ The objective of this modelling was to estimate the fit measure corresponding to a simplified factor structure, as shown in Table 5. First, exploratory factor analysis (EFA) was conducted to detect the presence of latent factors that can account for common variation in observed variables. The results are summarized in Tables 3 and 4. Second, this EFA loading structure was converted into a structure in which small loadings were set to 0 , and the larger loadings retained. Whenever individual items loaded on more than one factor, the largest item loading was retained. As a result, each of the 6 factors were characterized by a distinct set of items. In contrast to the EFA,

\begin{tabular}{|l|l|c|c|c|c|c|c|}
\hline \multicolumn{2}{|l|}{ Table 3. Three-factor solution model of owner experience } \\
\hline \multicolumn{2}{|l|}{} & \multicolumn{2}{|c|}{ Scenario 1 (n=103 cases) } & \multicolumn{3}{|c|}{ Scenario 2 (309 cases) } \\
\hline & Experience index & Basic & $\begin{array}{c}\text { High- } \\
\text { Level }\end{array}$ & Technology & Basic & $\begin{array}{c}\text { High- } \\
\text { Level }\end{array}$ & Technology \\
\hline 1 & Small business management & 0.683 & 0.000 & 0.116 & 0.613 & 0.000 & 0.047 \\
\hline 2 & Small business regulation & 0.498 & -0.035 & 0.033 & 0.334 & 0.083 & 0.150 \\
\hline 3 & Business plans & 0.301 & 0.353 & 0.034 & 0.358 & 0.326 & 0.104 \\
\hline 4 & Operations management & 0.641 & 0.239 & -0.132 & 0.627 & 0.058 & -0.020 \\
\hline 5 & Project management & 0.523 & 0.124 & -0.001 & 0.442 & 0.116 & -0.067 \\
\hline 6 & On-line communications & 0.089 & -0.131 & 0.911 & 0.105 & -0.103 & -0.888 \\
\hline 7 & Software skills & 0.114 & -0.049 & 0.807 & 0.084 & -0.029 & -0.787 \\
\hline 8 & Financial reporting & 0.302 & 0.273 & 0.292 & 0.202 & 0.325 & -0.174 \\
\hline 9 & Accessing industry information & 0.018 & 0.756 & 0.017 & -0.231 & 0.758 & 0.001 \\
\hline 10 & Financial analysis & 0.277 & 0.632 & 0.060 & 0.032 & 0.694 & -0.033 \\
\hline 11 & People management & 0.586 & 0.082 & 0.071 & 0.603 & 0.017 & -0.137 \\
\hline 12 & Professional networks & 0.350 & 0.210 & -0.142 & 0.376 & 0.125 & -0.056 \\
\hline 13 & Delegating & 0.560 & 0.087 & 0.048 & 0.664 & 0.039 & -0.097 \\
\hline 14 & Pricing & 0.813 & -0.329 & 0.061 & 0.788 & -0.178 & -0.004 \\
\hline 15 & Supplier/client relationships & 0.820 & -0.135 & -0.084 & 0.784 & -0.143 & 0.052 \\
\hline 16 & New product development & 0.275 & 0.404 & 0.046 & 0.242 & 0.372 & 0.024 \\
\hline 17 & Using market research & -0.082 & 0.873 & -0.049 & 0.019 & 0.756 & 0.059 \\
\hline 18 & Promotion and advertising & 0.072 & 0.484 & 0.131 & 0.231 & 0.360 & -0.052 \\
\hline 19 & Electronic commerce & -0.105 & 0.407 & 0.614 & -0.169 & 0.446 & -0.569 \\
\hline 20 & Adopting new technology & -0.258 & 0.592 & 0.559 & -0.139 & 0.568 & -0.411 \\
\hline 21 & Accessing fields of knowledge & -0.156 & 0.837 & 0.138 & 0.056 & 0.515 & -0.086 \\
\hline 22 & Industry standards & -0.009 & 0.653 & -0.098 & 0.072 & 0.479 & 0.153 \\
\hline 23 & Sources of capital & 0.166 & 0.724 & -0.225 & 0.053 & 0.603 & 0.163 \\
\hline
\end{tabular}

7. The sample of 103 respondents included respondents who indicated some level of experience. The sample of 309 respondents included all respondents, including those who indicated the experience was "not applicable." In the latter case, not applicable responses were concerted to $1=$ limited or no experience. The conversion was predicated on the assumption that business owners who perceived the stock of experience to be not applicable are less likely to seek this stock of experience and hence are more likely to have no or little experience. 


\begin{tabular}{|c|c|c|c|c|c|c|c|c|c|c|c|c|c|}
\hline \\
\hline \multicolumn{14}{|c|}{ Table 4. Six-factor solution model of owner e } \\
\hline & Experience 1 Index & 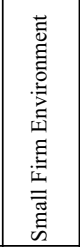 & 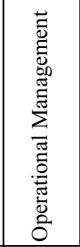 & 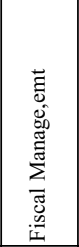 & 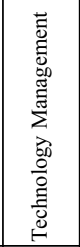 & 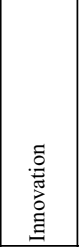 & 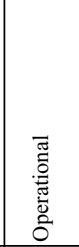 & 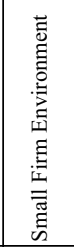 & 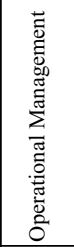 & 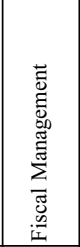 & 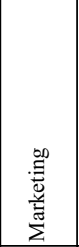 & 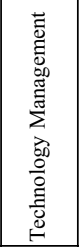 & 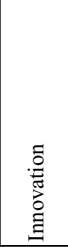 \\
\hline 1 & Small business management & 1.092 & $\mid-0.159$ & $\mid-0.114$ & 0.151 & 0.057 & 0.198 & 0.743 & 0.073 & -0.061 & -0.112 & 0.053 & 0.105 \\
\hline 2 & Small business regulation & 0.468 & 0.106 & 0.022 & 0.020 & -0.101 & 0.065 & 0.648 & -0.155 & 0.085 & -0.117 & -0.054 & 0.054 \\
\hline 3 & Business plans & 0.181 & 0.044 & 0.443 & 0.030 & -0.041 & 0.077 & 0.253 & 0.184 & 0.400 & 0.090 & -0.057 & -0.119 \\
\hline 4 & Operations management & 0.234 & 0.414 & 0.134 & -0.132 & 0.087 & 0.188 & 0.128 & 0.587 & 0.036 & -0.025 & \begin{tabular}{|l|}
-0.035 \\
\end{tabular} & 0.086 \\
\hline 5 & Project management & -0.109 & 0.885 & -0.191 & \begin{tabular}{|l|}
-0.059 \\
\end{tabular} & 0.212 & 0.068 & 0.138 & 0.335 & 0.094 & 0.095 & 0.055 & 0.013 \\
\hline 6 & On-line communications & 0.181 & -0.136 & -0.090 & 0.899 & 0.101 & 0.058 & 0.001 & 0.073 & -0.056 & $\mid-0.064$ & 0.820 & 0.119 \\
\hline 7 & Software skills & 0.034 & 0.118 & 0.026 & 0.810 & -0.020 & $\mid-0.104$ & 0.038 & 0.006 & 0.115 & -0.042 & 0.821 & -0.043 \\
\hline 8 & Financial reporting & 0.117 & 0.397 & 0.342 & 0.285 & -0.130 & \begin{tabular}{|l|l|}
-0.290 \\
\end{tabular} & 0.297 & 0.018 & 0.468 & -0.058 & 0.252 & -0.084 \\
\hline 9 & \begin{tabular}{|l|} 
Accessing industry \\
information
\end{tabular} & -0.009 & -0.016 & 0.718 & 0.046 & 0.148 & -0.060 & -0.079 & -0.169 & 0.601 & 0.312 & 0.053 & 0.023 \\
\hline 10 & Financial analysis & 0.074 & 0.186 & 0.709 & 0.050 & -0.021 & \begin{tabular}{|c|}
-0.066 \\
\end{tabular} & -0.033 & 0.148 & 0.754 & 0.060 & 0.056 & -0.010 \\
\hline 11 & People management & -0.161 & 0.606 & 0.143 & 0.073 & -0.114 & 0.246 & -0.204 & 0.903 & 0.116 & -0.099 & 0.031 & -0.010 \\
\hline 13 & Delegating & -0.112 & 0.556 & 0.050 & 0.042 & 0.025 & 0.255 & 0.050 & 0.637 & -0.022 & 0.052 & 0.015 & 0.113 \\
\hline 14 & Pricing & 0.151 & 0.207 & -0.172 & 0.048 & -0.075 & 0.657 & 0.338 & 0.373 & -0.096 & 0.255 & 0.035 & -0.205 \\
\hline 15 & Supplier/client relationships & 0.105 & 0.119 & 0.067 & -0.093 & -0.081 & 0.769 & 0.397 & 0.253 & -0.188 & 0.342 & -0.031 & -0.101 \\
\hline 16 & New product development & 0.134 & -0.021 & 0.312 & 0.023 & 0.249 & 0.306 & 0.179 & -0.052 & 0.004 & 0.539 & 0.001 & 0.138 \\
\hline 17 & Using market research & -0.148 & -0.091 & 0.926 & -0.048 & 0.110 & -0.028 & -0.243 & -0.010 & 0.487 & 0.797 & -0.080 & -0.015 \\
\hline 18 & Promotion and advertising & -0.147 & \begin{tabular}{|l|l|}
-0.207 \\
\end{tabular} & 0.677 & 0.187 & -0.022 & 0.252 & -0.022 & 0.146 & 0.091 & 0.439 & 0.047 & 0.080 \\
\hline 19 & Electronic commerce & -0.044 & 0.082 & 0.079 & 0.558 & 0.478 & 0.028 & -0.044 & -0.056 & 0.075 & 0.100 & 0.527 & 0.413 \\
\hline 20 & Adopting new technology & -0.042 & 0.052 & 0.075 & 0.498 & 0.693 & -0.043 & 0.038 & -0.048 & -0.064 & 0.079 & 0.355 & 0.741 \\
\hline 21 & $\begin{array}{l}\text { Accessing fields of } \\
\text { knowledge }\end{array}$ & -0.064 & 0.054 & 0.453 & 0.050 & 0.593 & $\mid-0.029$ & -0.029 & 0.085 & 0.003 & 0.300 & 0.010 & 0.460 \\
\hline 22 & Industry standards & 0.289 & 0.086 & 0.244 & -0.194 & 0.518 & \begin{tabular}{|c|}
-0.186 \\
\end{tabular} & 0.141 & 0.147 & 0.194 & -0.103 & -0.204 & 0.407 \\
\hline 23 & Sources of capital & 0.052 & 0.054 & 0.712 & -0.234 & \begin{tabular}{|l|}
0.095 \\
\end{tabular} & 0.034 & 0.226 & -0.039 & 0.385 & 0.089 & \begin{tabular}{|l|}
-0.128 \\
\end{tabular} & 0.209 \\
\hline
\end{tabular}

which allowed each observed variable to load on more than one latent factor, the CFA assumes that each observed variable is related to only one latent factor.

The estimator selected for EFA is weighted least-squares (WLS) with mean and variance adjustment (WLSMV). This is an approved method to account directly for the discrete nature of the data. As described by Muthén and Muthén (2001), WLSMV provides consistent parameter estimates and approximate tests for ordinal variables. Since it could not be assumed that the factors were uncorrelated, the promax rotation which allows for the correlations among factors is used to derive and interpret loadings. The scree plot of the variance associated with each factor showed a bend at the fourth factor indicated the existence of three large eigenvalues. However, a six-factor solution would be recommended over a three-factor solution due to the number of eigenvalues greater than 1 . Although the three-factor solution offers ease of interpretation, RMSEA for the model (scenario $1-0.091$, scenario $2-0.078$ ) is above .06, which indicates inadequate data fit. Nevertheless, the three-factor solution is presented in Table 3 for scenarios 1 and 2 to show the basic structure of experience. Originally, the six-factor solution was not available for scenario 2 with all variables in the model due to a convergence problem. The problem was solved by dropping the variable measuring the level of owner's experience 
in professional networking. The decision to exclude that variable was based on low communality and a relatively low factor loading. The six-factor loadings for scenarios 1 and 2 are presented in Table 4. RMSEA for the six-factor solution is 0.039 and 0.035 (for scenario 1 and scenario 2 respectively).

The latent dimensions identified in the three-factor solution can be described as follows:

Factor 1 - Basic management experience consists of knowledge that can be developed on the job without formal education. Basic management experience includes small business management, small business regulation, operations management, project management, people management, professional networks, delegating, pricing, and supplier/client relationships.

Factor 2 -High-level management experience are encounters that involve specialized areas of business knowledge such as finance and marketing. They seem to be essential for owners of firms operating in unstable, rapidly changing and uncertain environments. High-level management experience reflects business planning, financial reporting, accessing industry information, financial analysis, new product development, using market research, promotion and advertising, adopting new technology, accessing fields of knowledge, knowledge of industry standards, and access to sources of capital.

Factor 3 - Technology management experience includes on-line communications, software skills, and electronic commerce.

Variables measuring stocks of experience related to business planning and financial reporting tend to cross-load on two factors. Their highest loadings appear to be under basic management competencies in Scenario I and under high-level management experience in Scenario II. Variables pertaining to electronic commerce and new technology adoption load highly on technology management and high-level management experience.

The six-factor solution for Scenario II offers additional breakdowns of basic managerial experience to SME managerial experience and general experience. High-level experiences were divided into fiscal and marketing. Additionally, experiences that implicitly support innovation were clustered under a factor representing "entrepreneurial" experience. The latent structure of experience described by the six-factor solution appears as follows:

Factor 1 - SME managerial experience includes small business management, small business regulation, pricing, and supplier/client relationships.

Factor 2 - General management experience is heavily loaded on operational and social and competencies and include operations management, project management, people management, professional networks, delegating.

Factor 3 - Fiscal experience includes financial reporting, accessing industry information, financial analysis, industry standards, and sources of capital.

Factor 4 - Marketing experience includes new product development, using market research, promotion and advertising, accessing fields of knowledge.

Factor 5 - Technology management experience includes on-line communications, software skills, electronic commerce, and adopting new technology.

Factor 6 - Innovation experience includes electronic commerce, adopting new technology, accessing fields of knowledge, and industry standards.

Since the six-factor solution was derived from the three-factor solution, the variables that loaded on two factors tend to have high loading on multiple factors. Although the six- 


\begin{tabular}{|c|c|c|c|c|}
\hline \multicolumn{2}{|c|}{ Table 5 CFA statistics for scenario II (n=309 cases) } \\
\hline & \multicolumn{2}{|c|}{ Theory-Based Models } & \multicolumn{2}{c|}{ Empirically Derived Models } \\
\cline { 2 - 5 } & Model I (6 Factors) & Model II (3 Factors) & 3-Factor Solution & 6-Factor Solution \\
\hline CFI & 0.768 & 0.670 & 0.826 & 0.835 \\
\hline TLI & 0.863 & 0.810 & 0.900 & 0.905 \\
\hline
\end{tabular}

factor solution for scenario 1 (with 103 respondents) closely resembles that obtained for scenario 2 (with 309 respondents), a few structural differences make it conceptually less appealing. Table 5 presents the CFA model fit index based on the factor loading obtained in scenario 2 with 309 cases. To be able to compare theoretical (a model that suggests entrepreneurial, managerial and industrial experiential stock) and the empirical models with the same number of variables, no additional scale item which cross-loaded on more than one factor has been dropped. The results of CFA suggest a considerable difference in the data fit between theory-based and empirically estimated models. Both the RMSEA value and the SRMR value are smaller for the empirically derived models than for theorybased models. The empirically estimated six-factor model has the best model fit compared to its competitors. Surprisingly, when observed variables are restricted to loading on one latent factor, the six-factor solution structure offers only minimal improvement to the model fit compared to the three-factor solution. It should be noted that the model fit statistics for the empirically estimated models would be lower if the models were cross-validated with a sample not used in the estimation of item parameters. Given the high number of parameters in the model, the size of the data is too small for the exercise. However, almost identical factor structures in scenarios 1 and 2 suggest that both three-factor and six-factor solutions are stable. This finding helps to explain why certain studies report on three types of experience or solutions (Chandler and Jansen, 1992; Netwon, 2001; Lee and Tsang, 2001) while others document additional types of experience or competencies (Woolgar et al., 1998; Iles and Yolles, 2002; Hansen, Sondergard and Meredith, 2002; Van Gils and Zwart, 2004).

\section{Depth and Breadth of Experience}

To examine the association between breadth (diversity) of owner experience and depth (years) of owner experience, a correlation analysis was conducted. Depth (years) of experience was significantly correlated with the factors underlying fiscal, SME managerial, and general management experience (corr $=0.219,0.193$, and 0.189 , respectively). Years of total managerial experience was also associated with marketing experience (corr $=$ 0.094). There is no significant relation between depth (years) of total managerial experience and technology management and innovation experiences. A similar relationship was found between the various dimensions or types of experience and total years of experience in the present business. Given the weight of evidence, hypothesis 2 (Breadth [diversity] of owner experience is associated with depth [years] of owner experience) was partially supported.

\section{Experience and Stage of Firm}

Tests of Equality of Group Means were again employed to examine the third set of hypotheses (Breadth [diversity] of owner experience is associated with stage of firm development; and entrepreneurial experience is associated with stage of firm development). For the growth- and mature-stage firms, with the exception of technology management experience, no statistically significant differences in the stocks of experience occur across the primary stages, growth or maturity. However, owners of growth-stage 
firms tended to show a higher level of technology management, innovation, general management, marketing, and fiscal experience than do mature businesses owners. Furthermore, SME managerial experience appears to prevail among business owners running firms at the mature stage. Given the weight of evidence, hypothesis $3 \mathrm{a}$ [breadth (diversity) of owner experience is associated with stage of firm development] and $3 \mathrm{~b}$ (entrepreneurial experience is associated with stage of firm development) were not supported. The dominant type of experience associated with growth firms was technology management.

\section{Experience and Owner Intention}

To explore if breadth (diversity) of experience is associated with owners' growth intentions and/or entrepreneurial experience is associated with owners' growth intentions, ANOVA analysis was conducted. At the variable level, adopting new technology, new product development, on-line communications, promotion and advertising, and software skills had the highest discrimination power between business owners who intend to grow and those who do not (p-value for univariate ANOVA ranges between .002 and .008). Consequently, owners who have relatively more marketing, entrepreneurial, and technical experience were more likely to manifest the desire to expand their business ( $\mathrm{p}$-value $=$ $0.005,0.07$, and 0.010 respectively). However, although managerial (SME) experience did not provide a statistically significant mean difference between business owners with opposite intentions, it constituted the only dimension of experience that seems to be negatively related with the decision to grow. Hence, hypothesis 3-Entrepreneurial experience is associated with owners' growth intentions for the firm-was supported.

\section{Discussion of Findings}

The results of this study reveal the complexity of the latent structure of experience. The model identified here appears to be a combination of stocks of experience postulated by traditional domains as well as the domains of technology and innovation. A six-factor solution was developed that included experiences related to: the small business environment (i.e., business regulations, previous small business management experience, preparing business plans, pricing, supplier/client relationships); operational management that reflects managerial and social competencies (i.e., operations management, project management, people management, professional networks, delegating); fiscal experience (i.e., financial reporting, financial analysis, industry standards, sources of capital accessing, industry information); marketing experience (i.e., new product development or commercializing ideas, using market research, promotion and advertising, accessing fields of knowledge); technical experience (i.e., on-line communications, software skills, electronic commerce/procurement, adopting new technology); and innovation experience (i.e., electronic commerce/procurement, adopting new technology, accessing fields of knowledge, industry standards). This sixth factor (innovation) serves to identify further specific experience associated with the sometimes ambiguous dimensions of innovation. As such, the study does not support the hypothesis that owner experience can be delineated as functional, managerial and entrepreneurial, as described previously by Chandler and Jansen, 1992; Newton, 2001; and Lee and Tsang, 2001. These findings also challenge the literature that suggests experience can be defined through functional or traditional management nomenclature (Orser, 1997; Zinger et al., 2001), disciplinary domains that continue to underlie many educational training programs. "Entrepreneurial" experience appears to be both a subset of traditional disciplinary experience as well as a reflection of 
technology management and innovative experience. This observation is consistent with previous studies that identify technology as a unique competence of the business owner (Zinger et al., 2001; McCowan et al., 2001).

There is no significant relation between depth (years) of total managerial experience and technology management and innovation experience. A similar relationship was found between the various dimensions or stocks of experience and years of business experience in the present business. It appears that some (e.g., fiscal, SME managerial, and general management) stocks of experience are more likely to be acquired over time; this is not the case for experiences associated with technology management and innovation. ${ }^{8}$

It was surprising to the research team and funding agency that so many business owners considered experience associated with technology management and innovation to be "not applicable." Several rationales are advanced, speculation that motivates future research. Perhaps the very nature of technology management and innovation (e.g., unstable, constantly changing) results in a lower estimate of perceived experience by respondents in comparison to more static types of experience (e.g., fiscal and general SME management). Perhaps technology and innovation experience are considerably more difficult to acquire (e.g., necessitating scientific, mechanical or specialized acumen) and hence are far less likely to be a product of on-the-job learning or to translate into value-add for the enterprise. This argument is consistent with McGowan et al. (2001: 126), who examined factors that influence the adoption of Internet technology within small firms. Adoption was hypothesized to be contingent upon the development of competencies such as vision, value, technical ability and control. Their results indicate that application was most often limited to information gathering. While some entrepreneurs displayed technical competence, the primary challenge "... came in contextualizing this general usefulness to the situation specific to the individual entrepreneur." Most respondents were not conscious of the value or benefits that the technology could offer their firm. Alternatively, perhaps technology management and innovation are better acquired through others' labour (e.g., employees, contractors, suppliers). This rationale is consistent with McGowan et al. who also found that many business owners draw from personal (often family) contact networks for technical competence.

This research also found that the growth stage of firm development was associated with technology management experience. No empirical link was found between stage of firm and the remaining stocks of experience. One - perhaps obvious - rationale is that the presence of technological experience is associated with relatively efficient enterprise and hence, firms that are more likely to survive or grow. Alternatively, perhaps the nature of experience associated with the acquisition of technology is similar to the knowledge required to manage enterprise growth (e.g., ability to adapt and/or learn; ability to synthesize and apply new information). Alternatively, perhaps most business owners simply underestimate the importance of technological experience and that it is those business owners who understand the value of technological experience that are most likely to achieve business growth. This latter observation is consistent with the findings of McGowan et al. (2001), and our discussion about the high percentage of survey respondents who deemed technology-related experience to be "non-applicable." While future research is required to ascertain the underlying factors that influence owners' perceptions about technology management and innovation experience, these observations suggest that

8. This observation is not due to the apparent low level of interest by many respondents (e.g., $43.6 \%$ of respondents indicated that "electronic commerce"), as the analysis controlled for these responses. 
industry associations and training agencies might alert stakeholders about the merit of training targeted specifically at technology and innovation.

Finally, there appears to be an association between owners who have acquired marketing, innovation and technical experience and the desire to expand the business. This observation reinforces research that reports that owner experience links to intention (Orser, 1997). This observation also supports arguments that higher-level types of experience are manifested in owners that seek to grow the firm. For example, these owners have adopted technology and perceive a direct application of this experience to their business. They also understand how innovation (adopting industry technology, accessing new fields of knowledge, e-based commerce) is used to grow the firm. This result is inconsistent with that of Zinger et al. (2001). Employing the four-factor solution of "activity" or capability (managerial, marketing, financial/operations and technological), marketing and financial/operations were positively associated with performance. Technological capability was not. It may be that intention is a filter that moderates the influence of technology. Alternatively, the measure of technology used did not fully capture the nature of the competence (e.g., the factor contained only one measure-computer technology). Again, research is required to determine the intensity and causality of this association. For example, does technological and innovation experience motivate owners' growth intentions or is intention the driver that assists business owners in acquiring experience required to grow their firm? Nevertheless, these observations encourage future work to test and measure the experience construct.

\section{Study Limitations}

Experience is but one of many cognitive influences on organizational performance. It is also yet to be determined the degree to which experience is predictive of future performance outcomes. As Reuber and Fischer (1995: 3) write, the use of past experience is limited to the extent that it is by definition "in the past and is the antecedent of present or future states." Readers are therefore cautioned that experience might be considered both asset and liability. As Smith and Morse (2005: 8) summarize: "While more experience can be beneficial due to improved self-efficacy and information processing capacity, it can result in the loss of creativity or innovativeness, which can be critical in a changing competitive environment (Reuber and Fischer, 1999; Starr and Bygrave, 1992)." It should be recognized therefore that while this paper focused on the modelling of experience, future work is required to determine the relative influence of experience on competence and expertise.

This work was limited to a single informant, the small-business owner. While this is consistent with the respondent typology advanced by Reuber and Fischer $(1994,1999)$, it is also reasonable to assume that additional experience is provided to the organization through family members, mangers, advisers, etc. As such, future research should embrace an expanded sample, one that includes referent others such as members of the management team and advisors. In addition to the above research question, further study is also required to determine how experience is acquired.

This study employed a limited number of measures to estimate owners' experience and intentions. Future research might also employ different types of measures (other than Likert) in order to test further the reliability and stability of the experience indices. Future research might also expand the attributes ascribed to technology and innovation experiences given that these influences appear less likely to be acquired through on-the-job experience and yet are also associated with enterprise growth.

It is suggested that future research control for sector in order to better estimate the 
influence of technological experience on firm performance. Finally, there are several schools of thought about the merit of trait-based research. While scholars have called for research that examines the characteristics and attributes of business owners, others seek to ascertain the process and context that influence business decisions prior to examination of entrepreneurial outcomes (Aldrich and Martinez, 2001). This particular study was limited to the testing of previously defined experiences. Development of robust entrepreneurial psychometrics and diagnostics will benefit from multiple methods of analysis that encompass multiple perspectives, all in the context of a substantially larger study framework.

\section{Acknowledgements}

The authors would like to acknowledge and thank the anonymous reviewer who motivated much of the discussion contained in this section of the paper. The authors also wish to acknowledge the important contributions of the Women's Enterprise Initiative (Western Economic Diversification), Ginny Devine (Viewpoints Research Ltd.), Kelly Love (Equinox Management), Erwin Dreessen and Don Harrison (Small Business Policy Branch, Industry Canada). All errors and omissions are the responsibility of the authors.

\section{Contact Information}

For further information on this article, contact

Dr. Barbara Orser, Deloitte Chair in the Management of Growth Enterprises, School of Management, University of Ottawa, 136 Jean-Jacques Lussier Street, Ottawa, Ontario K1N 6N5

Phone: (613) 562-5800, Ext. 4570

E-mail: orser@management.uottawa.ca

\section{References}

Abraham, S., L. Karns, K. Shaw and M. Menam. 2001. "Managerial Competencies and the Managerial Performance Appraisal Process," Journal of Management Development 20, nos. 9-10: 842-53.

Acar, A. 1993. "The Impact of Key Internal Factors on Firm Performance: An Empirical Study of Small Turksih Firms,” Journal of Small Business Management 31, no. 4: 86-92.

Aldrich, H. and C. Zimmer. 1986. "Entrepreneurship through Social Networks." Pp. 3-23 in D. Sexton and R. Smilor (eds.), The Art and Science of Entrepreneurship. Cambridge, MA: Ballinger.

Aliouat, B., C. Camion and Y. Gasse. 1999. "Managerial Practices and Core Competencies of Entrepreneurs: A Contingency Framework of Performance," Frontiers of Entrepreneurship Research, Babson College, Babson Park, MA: http://www.babson.edu/entrep/fer/papers99/XXVII/XXVII_C/XXVII_C.html

Baldwin, J. 1993. Strategies for Success. A Profile of Growing Small and Medium-sized Enterprises (GSMEs) in Canada. Ottawa: Statistics Canada.

Baldwin, J.R., W. Chandler and C. Le Papailiadis and T. Papailiadis. 1994. Strategies for Success: A Profile of Growing Small and Medium-Sized Enterprises in Canada. Ottawa: Statistics Canada, Analytical Studies Branch. Catalogue No. 61-523-RPE.

Bates, T. 1990. "Entrepreneur Human Capital Inputs and Small Business Longevity," The Review of Economics and Statistics 4: 551-59.

Belenky, M., B. Clinchy, N. Goldberger and J. Tarule. 1986. Women's Ways of Knowing. New York: Basic Books Inc.

Boyatzis, R. 1982. The Competent Manager, A Model for Effective Performance. New York: John Wiley and Sons.

Chandler, G. and S. Hanks. 1994. "Founder Competence, the Environment, and Venture Performance," Entrepreneurship, Theory and Practice (Spring): 77-89.

Chandler, G. and E. Jansen. 1992. "The Founder's Self-assessed Competence and Venture Performance," Journal of Business Venturing 7: 223-36.

Chen, C., P. Greene and A. Crick. 1998. "Does Entrepreneurial Self-efficacy Distinguish Entrepreneurs from managers?," Journal of Business Venturing 13: 295-316.

Cliff, J. 1998. "Does One Size Fit All? Exploring the Relationship Between Attitudes Towards Growth, Gender and Business Size," Journal of Business Venturing 13, no. 6: 523-42.

Connally, J., K. Jorgenson, S. Gillis and P. Griffin. 2003. "A Multi-source Measurement Approach to the Assessment of Higher Order Competencies." Paper presented to the New Zealand Association for Research in Education, Auckland. 
Cooper, A., C. Woo and W. Dunkelberg. 1989. "Entrepreneurship and the Initial Size of Firms," Journal of Business Venturing 4: 317-32.

Cressy, R. 1994. "Staying With It: Some Fundamental Determinants of Business Start-up Longevity.” Warwick University: The Centre for Small and Medium Sized Enterprise Working Paper Series.

Cummins, D., A. Gilmore and D. Carson. Undated. "Examining the Nature of Marketing Decision-making Competencies in SMEs Over Time." School of Management, University of Ulster. (http://business.kingston.ac.uk/specials/meipaper/mktdecs.pdf )

Deakins, David and Mark Freel. 1998. "Entrepreneurial Learning and the Growth Process in SMEs," The Learning Organization 5, no. 3: 144-55.

Department of Trade and Industry. 2004. A Strategic Framework for Women Entrepreneurs. London: n.p.

Droge, C., S. Vickery and R. Markland. 1994. "Sources and Outcomes of Competitive Advantage: An Exploratory Study of the Furniture Industry," Decision Sciences 25, nos. 5-6: 669-89.

Dyke L., E. Fischer and R. Reuber. 1992. "An Inter-industry Examination of the Impact of Experience on Entrepreneurial Performance,” Journal of Small Business Management 30, no. 4: 72-87.

Edelman, L., C. Brush and T. Manolova. 2005. "Co-alignment in the Resource-Performance Relationship: Strategy as Mediator," Journal of Business Venturing 20: 359-84.

Encarta on-line Dictionary. 2006. Accessed on October 26, 2006 at http://encarta.msn.com/.

Eyre, P. and C. Smallman. 1998. "Euromanagement Competencies in Small- and Medium-sized Management Enterprises: A Development Path for the New Millennium?," Management Decision 31, no. 1: 34-42.

Freel, M. 1998. "Policy, Prediction and Growth: Picking Start-up Winners?," Journal of Small Business and Enterprise Development 5, no. 1: 19-32.

- 1999. "Where are the Skills Gaps in Innovative Small Firms?," International Journal of Entrepreneurial Behaviour and Research 5, no. 3: 144-54.

- 2000. "Towards an Evolutionary Theory of Small Firm Growth," Journal of Enterprising Culture 8, no. 4: $321-342$.

Gasse, Y. 1997. "Entrepreneurial-Managerial Competencies and Practices of Growing SMEs.” Working paper, University of Laval Centre for Entrepreneurship and SMEs.

- 1998. "Entrepreneurial Competencies and Practices of Growing SMEs," Frontiers in Entrepreneurship, Babson College, Babson Park, MA: http://www.babson.edu/entrep/fer/papers98/index98/index98.html

Gilligan, C. 1982. In a Different Voice: Psychological Theory and Women's Development. Cambridge: Harvard University Press.

Hansen, Ole, Bent Sondergard and Sandra Meredith. 2002. "Environmental Innovations in Small and Medium Size Enterprises," Technology Analysis and Strategic Management 14, no. 1.

Hu, L. and P.M. Bentler. 1999. "Cut-off Criteria in Fix Indexes in Covariance Structure Analysis: Conventional Criteria Versus New Alternatives," Structural Equation Modeling 6, no. 1: 1-55.

Industry Canada. 2004. Key Small Business Statistics. Ottawa: Industry Canada.

Iles, Paul and Maurice Yolles. 2002. "Across the Great Divide: HRD, Technology Translation, and Knowledge Migration in Bridging the Knowledge Gap Between SMEs and Universities," Human Resource Development International 5, no. 1: 23-53.

Jaskolka, G., J.M. Beyer and H.M. Trice. 1985. "Measuring and Predicting Managerial Success," Journal of Vocational Behaviour 26: 189-205.

Judge, T.A., D.M. Cable, J.W. Boudreau and R.D. Bretz. 1995. “An Empirical Investigation of the Predictors of Executive Career Success,” Personnel Psychology 48: 485-519.

Julien, Pierre-André and Charles Ramangalahy. 2003. "Competitive Strategy and Performance of Exporting SMEs: An Empirical Investigation of the Impact of Their Export Information Search and Competencies," Entrepreneurship Theory and Practice (Spring): 227-45.

Keeley, R. and J. Roure. 1990. "Management Strategy and Industry Structure as Influences on the Success of New Firms," Management Science 10: 1256-67.

Krueger, N. and A. Carsrud. 1993. "Entrepreneurial Intentions: Applying the Theory of Planned Behavior," Entrepreneurship and Regional Development 5: 315-30.

Krueger N., M.D. Reilly and A.L. Carsrud. 2000. "Competing Models of Entrepreneurial Intentions," Journal of Business Venturing 15, no. 5: 411-32

Lee, D. and E. Tsang. 2001. "The Effects of Entrepreneurial Personality, Background and Network Activities on Venture Growth," Journal of Management Studies 38, no. 4.

Lefebvre, L. and E. Lefebvre. 2000. SMEs, Exports and Job Creation, Occasional Paper, No. 26. Ottawa: Industry Canada.

Leitch, C. 1995. "Entrepreneurial Teams, Venture Development and Venture Performance," Frontiers in Entrepreneurship Research, Babson College, Babson Park, MA: http://www.babson.edu/entrep/fer/papers95/index.html

Lievens, F., J. Sanchez and W. DeCorte. 2004. "Easing the Inferential Leap in Competency Modelling: The 
Effects of Task-related Information and Subject Matter Expertise," Personnel Psychology 57, no. 4: 881-904.

Man, Thomas and T. Lau. 2000. "Entrepreneurial Competencies of SME Owner/Managers in the Hong Kong Services Sector: A Qualitative Analysis," Journal of Enterprising Culture 8, no. 3: 235-54.

McCall, M. and A. Morrison. The Lessons of Experience. Lexington, MA: Lexington Books.

McGee, J. and M. Peterson. 2000. "Toward the Development of Measures of Distinctive Competencies among Small independent Retailers," Journal of Small Business Management 38, no. 2: 19-34.

McGee, J., M. Dowling and W. Megginson. "Cooperative Strategy and New Venture Performance. The Role of Business Strategy and Experience," Strategic Management Journal 16: 565-80.

McGowan, P., M. Durkin, L. Allan, C. Dougan and S. Dixon. 2001. "Developing Competencies in the Entrepreneurial Small Firm for Use of the Internet in the Management of Customer Relationships," Journal of European Industrial Training 25, nos. 2-4: 126-36.

Melamed, T. 1996. "Validation of a Stage Model of Career Success," Applied Psychology: An International Review 45, no. 1: 35-65.

Mitchell, Ronald K., Robert Mitchell and J. Brock Smith. 2004. "Failing to Succeed: New Venture Failure as a Moderator of Startup Experience and Startup Expertise," Frontiers in Entrepreneurship Research, Babson College, Babson Park, MA: http://www.babson.edu/entrep/fer/FER_2004/web-content/Contents/Summary.html

Muthén, L.K. and B.O. Muthén. 2001. Mplus User's Guide. Los Angeles, CA: Muthén and Muthén.

National Women's Business Council. 2003. Best Practices in Supporting Women Entrepreneurs in the United States. Washington: n.p.

Newton, K. 1995. Management Skills Development in Canada, Occasional Paper, No. 13. Ottawa: Industry Canada. Accessed at: http://strategis.ic.gc.ca/epic/site/eas-aes.nsf/en/ra01013e.html

Orser, B. 1997. "The Influence of Intention, Managerial Experience and Gender on Small Firm Growth" (PhD dissertation, University Of Bradford, Bradford, UK).

Orser, B. and S. Hogarth-Scott, S. 2003. "Opting for Growth: Gender Dimensions of Choosing Enterprise Development," Canadian Journal of Administrative Sciences 19, no. 3: 284-300.

Orser B. and A. Riding. 2003. Management Competencies and SME Performance Criteria: A Pilot Study. Ottawa: Small Business Policy Branch, Industry Canada.

Penrose, E. 1957/1995. The Theory of the Growth of the Firm. London: Basil Blackwell.

Reuber, A. and Fischer, E. 1994. "Entrepreneurs' Experience, Expertise and the Performance of Technologybased Firms," IEEE Transactions on Engineering Management 41, no. 4: 365-75.

. 1995. "Reconceptualizing Entrepreneurs' Experience." Presentation to the Academy of Management (Vancouver, May).

- 1997. "The Influence of the Management Team's International Experience on the Internationalization of SMEs," Journal of International Business Studies 28, no. 4: 807-26.

- 1999. "Understanding the Consequences of Founders' Experience," Journal of Small Business Management 37, 2: 30-46.

Rosa, P., S. Carter and D. Hamilton. 1994. "Gender and Small Business Performance." Paper presentation to the 20th Small Firms and Policy Research Conference, Sheffield, England.

Shane, S. 1996. "Hybrid Organizational Arrangements and Their Implications for Firm Growth and Survival: A Study of New Franchisers," Academy of Management Journal 39, no. 1: 216-34.

Smith, Brock and Eric Morse. 2005. Entrepreneurial Competencies: Literature Review and Best Practises. Ottawa: Small Business Policy Branch, Industry Canada.

Snow, C. and L. Hrebiniak. 1980. "Strategy, Distinctive Competence and Organizational Performance," Administrative Science Quarterly 25: 317-36.

Starr, J. and W. Bygrave. 1992. "The Second Time Around: The Outcomes, Assets and Liabilities of Prior Startup Experience." Pp. 340-63 in Sue Birley and Ian MacMillan (eds.), International Perspectives on Entrepreneurship Research. Amsterdam: North Holland.

Stuart, R.W. and P.A. Abetti. 1990. "Impact of Entrepreneurial and Managerial Experience on Early Performance," Journal of Business Venturing 5: 151-62.

VandeVen, A, R. Hudson and D. Schroeder. 1984. "Designing New Business Start-ups: Entrepreneurial, Organizational and Ecological Considerations," Journal of Management 10: 87-108.

Van Gils, Anita and P. Zwart. 2004. "Knowledge Acquisition and Learning in Dutch and Belgian SMEs: The Role of Strategic Alliances," European Management Journal 22, no. 6: 685-92.

Woolgar, S., J. Vaux, P. Gomes, J. Ezingeard and R. Grieve. 1998. "Abilities and Competencies Required, Particularly by Small Firms, to Identify and Acquire New Technology," Technovation 18, nos. 8-9: 575-84.

Ziner, T., R. LeBrasseur and L. Zanibbi. 2001. "Factors Influencing Early Stage Performance in Canadian Microenterprises," Journal of Developmental Entrepreneurship 6, no. 2: 129-51. 


\section{Appendix A: Experiential Index}

\begin{tabular}{|c|c|c|c|c|c|c|c|c|c|}
\hline \multicolumn{10}{|c|}{$\begin{array}{l}\text { How would you rate your business experience, where } 1=\text { limited management experience, } 3=\text { some management experience and } 5=\text { extensive man- } \\
\text { agement experience?" If the experience criteria are not applicable to you or your firm, indicate "not applicable" (NA). }\end{array}$} \\
\hline \multicolumn{10}{|l|}{ General Management } \\
\hline $\begin{array}{l}\text { Small business } \\
\text { management }\end{array}$ & $\begin{array}{l}\text { Limited or no small business manage- } \\
\text { ment experience. (Never owner or oper- } \\
\text { ated a business, never worked in a small } \\
\text { firm). }\end{array}$ & NA & 1 & 2 & 3 & 4 & 5 & DK & $\begin{array}{l}\text { Extensive small business management } \\
\text { experience (e.g., owned and/or operated } \\
\text { a small firm(s) for at least } 5 \text { years.) }\end{array}$ \\
\hline $\begin{array}{l}\text { Small business } \\
\text { regulation }\end{array}$ & $\begin{array}{l}\text { Not familiar with small business regula- } \\
\text { tions such as licensing, permits. }\end{array}$ & NA & 1 & 2 & 3 & 4 & 5 & DK & $\begin{array}{l}\text { Very familiar with small business regu- } \\
\text { lations such as licensing, business } \\
\text { permits. }\end{array}$ \\
\hline $\begin{array}{l}\text { Preparing business } \\
\text { plan }\end{array}$ & No experience preparing business plans. & NA & 1 & 2 & 3 & 4 & 5 & DK & $\begin{array}{l}\text { Extensive experience developing/ exe- } \\
\text { cuting business plans. }\end{array}$ \\
\hline $\begin{array}{l}\text { Operations } \\
\text { management }\end{array}$ & $\begin{array}{l}\text { No experience managing multiple } \\
\text { departments within a business unit or } \\
\text { firm. }\end{array}$ & NA & 1 & 2 & 3 & 4 & 5 & DK & $\begin{array}{l}\text { Extensive experience and accountability } \\
\text { for managing multiple departments } \\
\text { within a business unit or firm. }\end{array}$ \\
\hline Project management & $\begin{array}{l}\text { No experience (e.g., integrate tasks, } \\
\text { logistics and make time estimates). }\end{array}$ & NA & 1 & 2 & 3 & 4 & 5 & DK & $\begin{array}{l}\text { Extensive experience integrating tasks, } \\
\text { in logistics and making time estimates. }\end{array}$ \\
\hline $\begin{array}{l}\text { On-line } \\
\text { communications }\end{array}$ & $\begin{array}{l}\text { No experience using on-line communi- } \\
\text { cations (e.g. Internet, e-mail). }\end{array}$ & NA & 1 & 2 & 3 & 4 & 5 & DK & $\begin{array}{l}\text { Extensive experience using on-line com- } \\
\text { munication (e.g., e-mail, Internet). }\end{array}$ \\
\hline Software skills & $\begin{array}{l}\text { No experience employing business soft- } \\
\text { ware in business decision-making (e.g., } \\
\text { word processing, spreadsheets). }\end{array}$ & NA & 1 & 2 & 3 & 4 & 5 & DK & $\begin{array}{l}\text { Extensive experience in employing busi- } \\
\text { ness software in business decision-mak- } \\
\text { ing (e.g., word processing, spread- } \\
\text { sheets). }\end{array}$ \\
\hline $\begin{array}{l}\text { Access to industry } \\
\text { information }\end{array}$ & $\begin{array}{l}\text { No experience accessing industry } \\
\text { information. }\end{array}$ & NA & 1 & 2 & 3 & 4 & 5 & DK & $\begin{array}{l}\text { Extensive experience accessing industry } \\
\text { information (e.g., retain consultants). }\end{array}$ \\
\hline \multicolumn{10}{|l|}{ Financial Management } \\
\hline Financial analysis & $\begin{array}{l}\text { No experience employing advanced } \\
\text { financial analysis (e.g., return on invest- } \\
\text { ment, share-of-market, pro-forma state- } \\
\text { ments). }\end{array}$ & NA & 1 & 2 & 3 & 4 & 5 & DK & $\begin{array}{l}\text { Extensive experience employing } \\
\text { advanced financial analysis (e.g., return } \\
\text { on investment, share-of-market, pro- } \\
\text { forma statements). }\end{array}$ \\
\hline Capital knowledge & $\begin{array}{l}\text { No knowledge about alternative sources } \\
\text { of capital (e.g., debt, equity, credit, ven- } \\
\text { ture capital). }\end{array}$ & NA & 1 & 2 & 3 & 4 & 5 & DK & $\begin{array}{l}\text { Extensive knowledge about alternative } \\
\text { sources of capital (e.g., debt and equity, } \\
\text { credit, venture capital). }\end{array}$ \\
\hline Financial reporting & $\begin{array}{l}\text { No experience with financial reporting, } \\
\text { tax planning or accounting practices. }\end{array}$ & NA & 1 & 2 & 3 & 4 & 5 & DK & $\begin{array}{l}\text { Extensive experience with financial } \\
\text { reporting, tax planning or accounting } \\
\text { practices. }\end{array}$ \\
\hline \multicolumn{10}{|l|}{ Human Resources } \\
\hline Employment skills & $\begin{array}{l}\text { No experience hiring, firing and manag- } \\
\text { ing others. }\end{array}$ & NA & 1 & 2 & 3 & 4 & 5 & DK & $\begin{array}{l}\text { Extensive experience hiring, firing and } \\
\text { managing others. }\end{array}$ \\
\hline Networks/Contacts & $\begin{array}{l}\text { Limited professional networks (e.g., } \\
\text { community, trade, industry contacts). }\end{array}$ & $\mathrm{NA}$ & 1 & 2 & 3 & 4 & 5 & DK & $\begin{array}{l}\text { Extensive professional networks (e.g., } \\
\text { community, trade, industry contacts). }\end{array}$ \\
\hline Ability to delegate & $\begin{array}{l}\text { No experience delegating to contractors } \\
\text { or employees. }\end{array}$ & NA & 1 & 2 & 3 & 4 & 5 & DK & $\begin{array}{l}\text { Extensive experience delegating to con- } \\
\text { tractors or employees }\end{array}$ \\
\hline \multicolumn{10}{|l|}{ Marketing } \\
\hline Pricing & $\begin{array}{l}\text { No experience pricing goods and/or } \\
\text { services. }\end{array}$ & NA & 1 & 2 & 3 & 4 & 5 & DK & $\begin{array}{l}\text { Extensive experience pricing goods or } \\
\text { services. }\end{array}$ \\
\hline $\begin{array}{l}\text { Performance stan- } \\
\text { dards }\end{array}$ & $\begin{array}{l}\text { Not familiar with industry quality or } \\
\text { performance standards (e.g., ISO guide- } \\
\text { lines). }\end{array}$ & NA & 1 & 2 & 3 & 4 & 5 & DK & $\begin{array}{l}\text { Very familiar with industry quality or } \\
\text { performance standards (e.g., ISO guide- } \\
\text { lines). }\end{array}$ \\
\hline $\begin{array}{l}\text { Client/supplier rela- } \\
\text { tionships }\end{array}$ & $\begin{array}{l}\text { Few relationships with (potential) } \\
\text { clients and/or suppliers. }\end{array}$ & NA & 1 & 2 & 3 & 4 & 5 & DK & $\begin{array}{l}\text { Extensive relationships and/or alliances } \\
\text { with suppliers and/or clients. }\end{array}$ \\
\hline $\begin{array}{l}\text { Commercializing } \\
\text { business ideas }\end{array}$ & $\begin{array}{l}\text { No experience developing and/or com- } \\
\text { mercializing a new product or service } \\
\text { idea or concept. }\end{array}$ & NA & 1 & 2 & 3 & 4 & 5 & DK & $\begin{array}{l}\text { Extensive experience commercializing a } \\
\text { new product or service concept. }\end{array}$ \\
\hline Market research & $\begin{array}{l}\text { No experience (e.g., competitive analy- } \\
\text { sis, market tested new product or serv- } \\
\text { ice, estimating demand). }\end{array}$ & NA & 1 & 2 & 3 & 4 & 5 & DK & $\begin{array}{l}\text { Extensive experience (e.g., competitive } \\
\text { analysis, market tested new service or } \\
\text { product, estimating demand). }\end{array}$ \\
\hline $\begin{array}{l}\text { Promotion and } \\
\text { advertising }\end{array}$ & $\begin{array}{l}\text { No experience with promotion or } \\
\text { advertising }\end{array}$ & NA & 1 & 2 & 3 & 4 & 5 & DK & $\begin{array}{l}\text { Extensive experience with promotion } \\
\text { and advertising (e.g., develop/execute } \\
\text { advertising and promotion campaign). }\end{array}$ \\
\hline \multicolumn{10}{|c|}{ Technology and Innovation } \\
\hline $\begin{array}{l}\text { Adopting industry } \\
\text { technology }\end{array}$ & $\begin{array}{l}\text { Not familiar with leading-edge tech- } \\
\text { nologies (e.g., business-to-business elec- } \\
\text { tronic marketing practices). }\end{array}$ & NA & 1 & 2 & 3 & 4 & 5 & DK & $\begin{array}{l}\text { Very familiar with leading-edge tech- } \\
\text { nologies (e.g., business-to-business elec- } \\
\text { tronic marketing practices). }\end{array}$ \\
\hline $\begin{array}{l}\text { Accessing new fields } \\
\text { of knowledge }\end{array}$ & $\begin{array}{l}\text { Little access to industry experts (e.g., } \\
\text { research and development groups). }\end{array}$ & NA & 1 & 2 & 3 & 4 & 5 & DK & \begin{tabular}{|l|} 
Extensive access with industry experts \\
(e.g., research and development groups).
\end{tabular} \\
\hline $\begin{array}{l}\text { E-based commerce } \\
\text { /procurement }\end{array}$ & $\begin{array}{l}\text { No experience buying and selling com- } \\
\text { mercial goods on the Internet. }\end{array}$ & NA & 1 & 2 & 3 & 4 & 5 & DK & $\begin{array}{l}\text { Extensive experience buying and selling } \\
\text { commercial goods on the Internet. }\end{array}$ \\
\hline
\end{tabular}

